\title{
Symbolic consultation and cultural simplification in the establishment of an Indonesian national park and its impacts on local livelihoods
}

\author{
Mei Meilani ${ }^{1, *}$, Wahyu Andayani ${ }^{2}$, Lies R.W. Faida ${ }^{2}$, Fitria D. Susanti ${ }^{1}$, Rodd Myers ${ }^{3}$, Ahmad \\ Maryudi ${ }^{1,4}$ \\ ${ }^{1}$ Sebijak Institute (Research Center for Forest Policy \& History), Faculty of Forestry, Universitas Gadjah \\ Mada, Yogayakarta, Indonesia \\ ${ }^{2}$ Faculty of Forestry, Universitas Gadjah Mada, Yogyakarta, Indonesia \\ ${ }^{3}$ Dala Institute, Jakarta, Indonesia \\ ${ }^{4}$ Leadership \& Policy Innovation Program, The Graduate School, Universitas Gadjah Mada, Yogyakarta, \\ Indonesia \\ * Correspondence author: meimei2018@mail.ugm.ac.id : Tel.: +62 812-8225-3874
}

\begin{abstract}
This paper analyzes the processes by which the Sebangau National Park in Central Kalimantan (Indonesia) was established, along with the management activities implemented and the impacts of such activities on local communities. Employing an environmental justice lens, which revolved around procedural, recognition, and distribution issues, we found that local communities were not adequately consulted or involved in the establishment and management of the national park. Furthermore, approaches to mitigate the adverse impacts failed to fully consider the diverse cultures and customs with different livelihood strategies surrounding the park. The research also found that the options made available for local livelihoods were limited and did not meet specific needs and demands of certain ethnic groups. Overall, the transformation of the Sebangau production forest into a conservation area significantly disrupted local livelihoods and led to pronounced adverse economic, social, and cultural impacts. Thus, adequate attention to environmental justice must be made if park authorities are to improve the social acceptability of the national park. They should meaningfully engage the local communities in decision-making procedures related to park management, because they are directly impacted by the park. The authorities should also understand the different sociocultural aspects related to the local people surrounding the park and their different needs and livelihood strategies. Finally, the livelihood alternatives should be carefully assessed, and locals should be adequately consulted to ensure that these are socially and culturally accepted.
\end{abstract}

Keywords: Environmental justice; Local livelihoods; Indigenous people; National parks; Protected areas; Participation; Indonesia

\section{Introduction}

The total size of areas dedicated for conservation and protection has increased from $12.7 \%$ in 2012 (Bertzky et al. 2012) to 15.2\% of the world's terrestrial area in 2020 (UNEP-WCMC, IUCN, and NGS, 2020). Many of these conservation areas were previously used for economic and production purposes. Conservation and protected areas are usually dedicated to the preservation of biodiversity and maintenance of ecological services. They are also crucial for alleviating climate change (Hannah, 2008). However, there have been growing concerns that the design and implementation of biodiversity conservation often lead to adverse social impacts on local communities (Dahlberg, 2010; Myers \& Muhajir, 2015; Bong et al., 2016, Fatem et al., 2018). This is because the process of establishing conservation areas often overlooks the sociocultural values of communities living near these areas (Infield, 2001; Hulme \& Murphree, 2001; Infield et al., 2017; O'Riordan \& Stoll-Kleemann, 2002; Abukari \& Mwalyosi, 2020). In fact, many local communities and indigenous groups have encountered challenges in sustaining their livelihoods owing to the use of forests and their natural resources for conservation purposes (Balmford \& Whitten, 2003; Baker et al., 2011, Bennett \& Dearden, 2014). In some cases, the gazettement of forest conservation has completely displaced local communities (Elmhirst, 2011; Agrawal \& Redford, 2009; Tauli Corvuz, 
2016). Thus, there has been a growing clamor for the equitable and just management of conservation and protected areas (Nurrochmat et al., 2017; Schreckenberg et al., 2016; Hart, 2014).

Sebangau National Park (SNP) in Central Kalimantan, Indonesia, was established in 2004 on areas that were previously used for logging operations. Its establishment primarily aimed at rehabilitating degraded peat swamp forests, while conserving the remaining intact peatland. However, similar to the case of other national parks in the country, it has been reported that the establishment of SNP has increasingly led to undesirable social impacts, such as land tenure issues, resource sharing, and access, resulting in conflicts between local communities and the national park authority (Soehartono \& Mardiastuti, 2013; Setiawan et al., 2016). In fact, a total of 50 villages with diverse sociocultural backgrounds and interactions with forest resources surround the SNP (for details, see Section 2).

Employing an environmental justice lens, this paper explores how the establishment of the SNP has led to adverse social, economic, and cultural impacts. To achieve the wise management of forest resources, the concept of environmental justice must be discussed directly in integrated conservation and economic growth programs (Gustavsson et al., 2014). Three key reasons explain why biodiversity protection is always linked to the concept of environmental (in)justice (Martin et al. 2016). First, protected areas are spatially correlated with cultural diversity. Second, traditional conservation approaches are often determined by popular (and sometimes controversial) ideas about what works and what counts as proof of what works. Third, local communities are rarely consulted after the declaration of a protected area (Martin et al., 2016).

The concept of environmental justice has evolved over time. Schlosberg (2013) pointed out that environmental justice has changed from a simple expression of social inequality to a broader statement on the critical existence of the relationship between the environment and the provision of justice itself. Environmental justice is typically used to imply deliberative democracy, equality, and fairness (Maryudi et al., 2020). In fact, several justice scholars avoided defining justice per se, and instead focused on the typologies, aspects, and requirements for justice to occur. Justice, in terms of conservation policy, is often conceptualized as the recognition of cultural diversity to establish common justice notions of access rights, distributional fairness, deliberative democracy in decision-making process, and the sharing of socioeconomic benefits (Walker, 2012; Martin et al., 2013).

Environmental justice has also been framed as a reflection of fairness and equity related to the notions of recognition, procedure, and distribution (Martin et al. 2016; Boillat et al. 2018; Maryudi \& Myers 2018). Here, "distribution" refers to differences among stakeholders, especially in terms of who enjoys rights to material benefits, on the one hand, and who bears costs and responsibilities, on the other hand (Schreckenberg et al. 2016). Recent scholarship highlights the importance of representation (procedure) and recognition (Sikor, 2013). "Procedure" refers to how decisions are made, who is involved, and on what terms (Schroeder et al, 2008; Schreckenberg et al., 2016), while "recognition" refers to respect for cultural differences and identities (Martin et al., 2016).

\section{Methods}

This study was carried out through a systematic and coordinated procedure that was guided by theories and expertise emphasizing the interaction between the SNP and the forest-dependent communities surrounding it. This work focused on the socioeconomic aspects, mainly the changes in their livelihood activities and strategies, and the driving factors revolving around the processes through which the national park SNP was established.

\subsection{Study area}

Sebangau forest had been used and managed as a traditional forest by the locals but was later officially proclaimed as the state's forest. In the 1970s, it was allocated as a production forest for logging operations. However, due to rampant logging, the forest was later listed as a deteriorated region, with a recovery obligation of $45 \%$ from the total area of 568,700 ha. Following this development, SNP was eventually established. The SNP lies in the municipality of Palangkaraya and the districts of Katingan and Pulang Pisau. A total of seven sub-districts comprising 50 villages with 15,176 households surround the park. The local communities surrounding the SNP can be classified 
into native tribes (e.g., Dayak Ngaju) and migrants (e.g., Banjar, Javanese, and Sundanese). Each group lives in a colony with specific livelihood options and local wisdoms and traditions. The main livelihoods of native tribes include farming, fishing, and timber cutting, while the migrants generally rely on trading and farming activities for their livelihoods. The livelihood patterns can also be classified according to the different characteristics of natural resources indigent to the eastern (Katingan River) and western (Sebangau River) sides of Sebangau forest. The diverse livelihood groups existing around SNP include local fishermen, farmers, gatherers of non-timber forest products, canal owners, loggers, daily laborers, traders, civil servants, consumers, and local dwellers (Persoon, 2004).

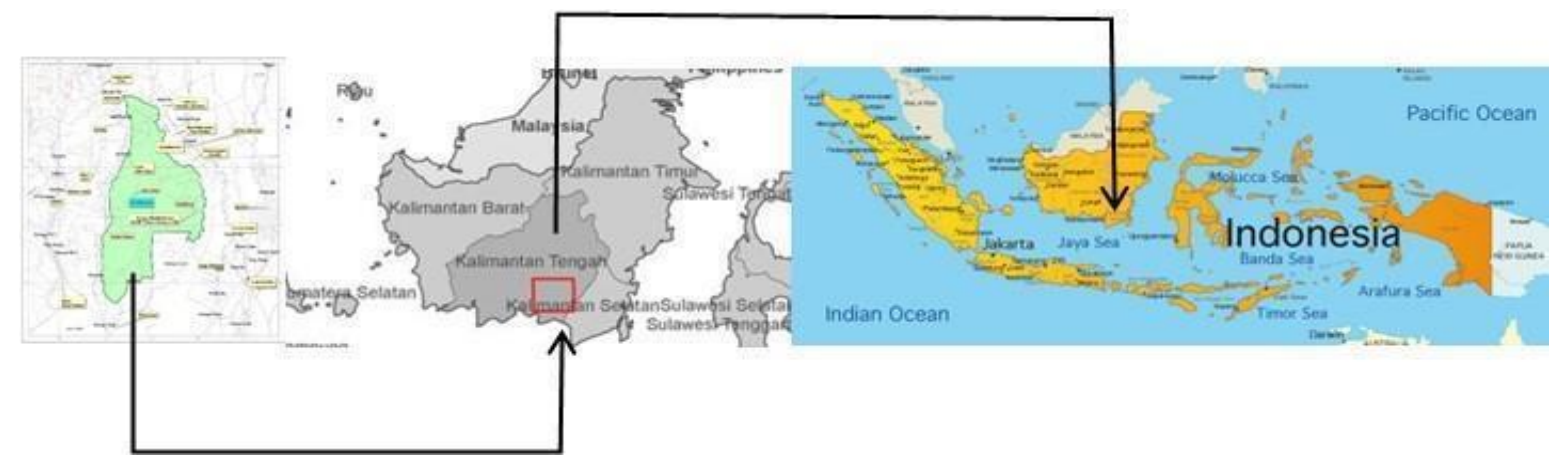

Figure 1. Study site

Three villages were selected based on variations in the following aspects: (1) types of livelihoods reliant on park resources (e.g., fishermen, farmers, gatherers of non-timber forest products, canal owners,, loggers, traders, and daily laborers, such as sawmill and canal employees); (2) locations and proximities to the forests (e.g., district, sub-district, rivers, and park zones); (3) types of village (e.g., traditional versus transmigrant); and (4) tribes (e.g., native Dayak, immigrant Banjar, Javanese, and Sundanese). The three research sites were Kereng Bangkirai, Baun Bango, and Mekar Tani.

Table 1. General Data of the Three Research Sites

\begin{tabular}{lccc}
\hline \multicolumn{1}{c}{ Type of Information } & Kereng Bangkirai & Villages & Maun Bango \\
\hline District & Palangkaraya & Katingan & Katingan \\
Sub-district & Sebangau & Kamipang & Mendawai \\
Population* & 5,609 & 868 & 992 \\
Type of village & Traditional & Traditional & Transmigrant \\
Tribes & Dayak, Banjar, Javanese & Dayak, Banjar, Javanese & Javanese, Dayak, \\
& & & Banjar \\
Occupation/ livelihood & Government employees, & Fishermen, Rattan & Farmers, Daily \\
sources & Farmers, Fishermen, Resin & gatherers, Ecotourism & laborers, Traders \\
& tapper of Dyera costulata & activities &
\end{tabular}

(Jelutung), Daily laborers, Traders

Closest SNP Zoning ** Rehabilitation Zone Rehabilitation Zone Utilization Zone

Sources : Balai Taman Nasional Sebangau, 2007a, 2007c, 2007d, 2010a; Persoon, 2004; Persoon \& Aliayub, 2002

Notes : ${ }^{*}$ The village has the highest population in their sub-district

** The village is located at the border of SNP

\subsection{Data collection and analysis}

Data were collected through different approaches based on the types of information and analysis needed to answer the research questions (Laraswati et al., 2020). In-depth interviews and focus group discussions (FGDs) were employed as the core research approach. In general, the data and information collected include the following:

(1) the process by which the SNP was established and management activities were implemented, 
and

(2) changes in the livelihoods of different forest-dependent communities surrounding the SNP.

Five FGDs were held in the three villages, with a total of 68 participants. In addition, 54 key informants, including national and local government officials, park managers and park officers, national and local NGO staff, and local community leaders and members, were interviewed. Then, a household survey was conducted as an additional approach to analyze the livelihoods of the local communities. The survey was specifically used to achieve the following goals: 1) to gather data on current socioeconomic conditions; 2) to understand the nature, magnitude, and direction of socioeconomic changes that may have occurred; and 3) to identify the preference of local communities for alternative livelihood options. Overall, this survey included 31 respondents from each village coming from a total of 93 households.

The analysis for secondary data aimed to achieve the following goals: (1) to describe the socioeconomic aspects of the livelihoods of local communities before and after the creation of the SNP; (2) to explain the objectives (or purposes) of the creation of the SNP; and (3) to investigate the documentation on the involvement of local communities in the management of national parks, including the implementation of government regulations, the management plans for various national parks in Indonesia, university research reports, conference papers, and local news (e.g., websites, magazines, newspapers). They can be useful data sources (Rahayu et al., 2019).

\section{Symbolic consultation and token participation}

As previously mentioned, the establishment of the SNP was centered around the following objectives: (1) conservation of the peat swamp ecosystem, (2) maintenance of the biodiversity and unique landscape, and (3) sustainable use of ecosystems and natural resources. Furthermore, as stated in the Park Management Plan 2007-2026, the specific goals of the SNP are as follows: (1) the protection and preservation of the tropical peat swamp forest ecosystem as a life support system; (2) the preservation of natural resources, especially endemic/protected/endangered species; and (3) the provision of sustainable benefits for various communities, particularly the local community.

In the 1970s, Sebangau forest was classified as a production forest dedicated for large-scale logging activities. At that time, 13 companies operated in this area. Thus, during the peak of the logging period, the villages surrounding the forest were flooded with migrant workers employed by the concession companies. As explained by a local community leader in Kereng Bangkirai, these migrant workers came from many regions, such as Sumatera, Java, West Kalimantan, and Sulawesi. The local communities of Kereng Bangkirai and Mekar Tani allowed log buyers (also called cukong) to come, stay, and bring their own laborers to the villages. In a typical transaction, a cukong used to do transactions with local community members. The latter functioned as intermediary traders, organizing timber-harvesting activities and making payments to the local laborers.

The logging operations were supposed to end by 1996 based on the logging permits that were granted in the area. However, logging and land-clearing activities continued until 1999. Another local community leader in Kereng Bangkirai suspected that some companies misused their Timber Utilization Permits, also known as Izin Pemanfaatan Kayu (IPK). They may have used these permits for the area of the Mega-Rice Project, supposedly granted for specific areas in Kapuas District, to also harvest timber in Sebangau forest. The Mega-Rice Project was a government program designed to create one million hectares of paddy fields in Southern Kalimantan beginning in 1995. However, this project failed to meet the intended objectives and was eventually terminated in 1999. The degraded project area has since been abandoned.

Following the national political reform by the end of the 1990s, a new governance arrangement was introduced in the country, with more authorities delegating the management of forests to local governments. As stipulated in Law No. 22 of 1999 on Local Governance ${ }^{1}$, regents (bupati) were authorized to issue small logging permits (maximum 100 ha), also known as Izin Pemungutan dan Pemanfaatan Kayu (IPPK), in production forest zones to be converted to other uses, excluding areas where concessions had already been granted (Rahman et al., 2012; Samsu et al., 2004). In Sebangau forest, the last IPPK-based logging company continued to operate until 2002, when the government,

\footnotetext{
${ }^{1}$ This Law was replaced by Law No. 32 of 2004 on Local Governance.
} 
through the Ministerial Decree No. 541/Kpts-II/2002, prohibited the issuance of new small-scale concessions by local governments. After this development, legal investors and sawmill companies eventually left the Sebangau forest area.

In the same year, the central government exercised the potential change of forest status into a conservation site; however, it did not carry out formal consultations nor did it provide information to the locals. Henceforth, the WWF-Central Kalimantan promptly began to raise awareness of the possible change in status of the Sebangau forest status. For some local communities, the WWF represented the meaning and function of conservation forests/protected areas/national parks, the general functions of the forest, and new rules that could significantly affect local communities, such as limited human activities in the area. As bemoaned by a village leader in Baun Bango:

We had no option but to obey the new regulations. We could do nothing. It was decreed by the President and conveyed to the Governor of Central Kalimantan Province, the Regent of Katingan District, the Leader of Kamipang Sub-District, and to me as the Leader of Baun Bango. It was my responsibility to communicate [the information] to the local community. I said to the community that I will not ban the community [members] from harvesting timber, but they must know the consequences of harvesting timber since the issuance of the new regulations.

Likewise, community leaders mentioned that they were invited to attend several events publicizing the central government's policy to establish the conservation area. The leaders were mostly from Kereng Bangkirai, the closest research site to Palangkaraya, the capital city of the Central Kalimantan Province. The communities of the other research sites were mostly out of reach due to the remote locations and difficulty in accessing these. Therefore, despite being invited, they were unable to participate in deciding whether to approve or reject the national park and were obliged to accept the decision. Our key informants suggested that events were only conducted to meet the regulatory obligation of public consultations, instead of a genuine approach to resolve conflicts with the local communities. Meanwhile, only a few community leaders were invited to participate in dialogs with the government, which were facilitated by the WWF, regarding the gazettement and conservation area zoning. Although the locals were provided with access zones, the zones were pre-determined by the park authorities and were not based on genuine dialogs and meaningful consultations. In other words, it was the government who made the entire decision; several interviewees mentioned that local people were only informed and were barely consulted about the coverage of the national park and the different types of zoning. As a result, the initial zoning did not fully satisfy the locals, as many of the daily activities were conducted in the prohibited zones, i.e., the core and forest/buffer zones.

At the end of 2004, the SNP was formally declared by the central government, as a result of which all logging businesses in the area were completely ceased and logging activities were prohibited. Following the establishment of the SNP, several NGOs-including the WWF, Borneo Foundation, and Padi-continued their respective programs to raise awareness of the forest's new status to wider communities. However, they were only able to provide limited explanations of the "rules of the game" for a national park. Thus, members of the local communities mentioned that they were in the dark over the activities permitted in the SNP.

The declaration of the national park was not swiftly followed by the establishment of an institution tasked with the day-to-day management of the park. Instead, the then Ministry of Forestry $(\mathrm{MoF})^{2}$ tasked the Provincial (Central Kalimantan) Bureau for Natural Resource Conservation (BKSDA) to become the SNP caretaker until the creation of the definitive Sebangau National Park Authority (SNPA) in June 2006. In the same year, as the Head of Mekar Tani explained, the SNPA created local community forums, also known as Forum Masyarakat (Formas), to facilitate further dialogs and negotiations between the management and local communities in relation to the institutional arrangements, plans, and strategies of the SNP. Six Formas were created as representatives of local communities at the sub-district level. However, they were not guided by clear selection structures and procedures. Moreover, the process by which the members were

\footnotetext{
${ }^{2}$ Now Ministry of Environment and Forestry (MoEF)
} 
selected was also questioned by local communities. For instance, a Formas in Kereng Bangkirai was composed of only members of the same immediate family. According to several respondents, their committee did not have good relations with the broader local communities. More importantly, the Formas had no decision-making power over certain matters pertaining to the national park. As suggested by our key informants, their only function was to channel information from the park authorities to the wider communities. A young fisherman from Kereng Bangkirai during an FGD summed up the Formas' roles as follows:

I heard about Formas, but it has done nothing for us. The committee only distributed information to people within their circle. I am sure they are there not to communicate to us (local communities), but only for the interest of the park management. I have never been invited to any gathering [that was trying to bridge differences] between the locals and the park authority. They do nothing. They are only a display, but no [genuine] meaning [for us].

With limited opportunities to participate in genuine consultations, it was but natural for several local communities to oppose the SNP establishment. For example, some communities continued to cut trees from the national park. As suggested by sources from BKSDA and SNPA, the SNPA was given the task of preventing further human disturbance on the degraded forest resource; thus, it arrested "illegal" loggers and sent them to jail. At one point, the SNPA even destroyed timber piles in Tumbang Bulan Village, a neighboring village to our study sites. These repressive measures had psychological effects, terrifying many of the locals, whose customary activities were now deemed illegal by the state.

\section{Cultural simplification and negligence}

There are two large ethnic groups surrounding Sebangau forest: the indigenous Dayak and the migrant Javanese. These groups have different interactions with the natural resources of Sebangau forest. For one, the Dayak community is heavily dependent on the forest to sustain their daily livelihoods as well as their cultural beliefs and practices. Several people from Dayak community mentioned that they consider the forest as a core part of their rich history, providing them with dietary products (food, fish, vegetables), medicine, clothing, and materials for shelter. The main activities for sustaining their livelihoods include fishing, bat \& and wildlife hunting, and collecting non-timber products, such as the resin of jelutung ${ }^{3}$ and pantung ${ }^{4}$ as well as the gemor ${ }^{5}$ tree bark. The intimate connection with the forest is also well reflected in the Dayak culture, such as in songs, rich motives in their clothing and accessories, as well as body paints and tattoos. Furthermore, their sacred tribal sites, where their gods and the ancestors' spirits rest, are also located in the forest. Meanwhile, the migrant Javanese do not directly rely on the forests, as they used to work in logging concessions and timber sawmills. When logging operations were abandoned, they sustained their livelihoods by conducting relatively permanent farming and raising livestock.

We found that the establishment of the SNP failed to sufficiently consider the different types of livelihoods, customs, and cultures of the communities surrounding the forest. Granted, several Dayak community leaders (known as damang) were invited to attend the government's dissemination events and were informed of the plan to change the forest into a conservation site. However, as previously mentioned, they were not adequately consulted, as those events were not held to obtain their informed consent, but simply to inform them of the government's plans. More importantly, the greater Dayak community was largely overlooked in establishing the park. In fact, many of the respondents stated that they were completely uninformed about the national park. The Formas that were envisioned to channel their aspirations did not function. The SNPA models and strategies have, in many cases, neglected and even harmed the culture and traditions of the Dayak. For instance, Dayak newlyweds used to claim forest land to start a new life, but they are no longer able to do so. Instead, they are forced to stay with their extended families until they have sufficient

\footnotetext{
${ }^{3}$ This refers to the resin material used in gum, tires, and paint production.

${ }^{4}$ This is useful for wound treatment.

${ }^{5} \mathrm{~A}$ highly marketable material that is used in the production of mosquito repellent.
} 
money to buy land and timber to build a house. In addition, there were no representatives of Dayak communities in the SNPA's management structures and institutional arrangements. As a (Dayak) community leader in Baun Bango remarked:

We have long extracted jelutung resin, pantung, traditional medicines, and damar resin. We have also relied on pig hunting and fishing. We have done these practices for a long time before the SNP was established, and now our activities are prohibited, making our lives difficult.

The change of forest status into conservation areas has also resulted in the prohibition of intensive human-forest interactions, particularly in the core and forest/buffer zones. As forest products became increasingly scarce, this led to fierce competition among community members for harvests. The conflicts over scarce resources were often reported by respondents as being along ethnic lines, thereby creating lasting rifts among rivaling factions. An old migrant in Mekar Tani reflected on this situation:

We understand that we are migrants here, and the forest does not belong to us. It belongs to the local people, Dayak people. If they said it is theirs, then it is better for us to stay away from it."

Sources from the SNPA mentioned, however, that the park has allocated several zones that allow human intervention. Furthermore, responding to concerns about the potential adverse impacts in terms of social, economic, and cultural issues, the park authorities have tried to accommodate several requests from the local people, including the gazettement of utilization zones in riparian areas along rivers and canals to allow the indigenous Dayak to conduct fishing activities and harvests of forest products upon the prohibitive rules of timber harvests. In fact, the SNPA has gazetted several "human interaction areas," including 1) utilization, 2) traditional, 3) rehabilitation, 4) religious-cultural-social, and 5) special zones that, altogether, comprise approximately $30 \%$ of the total conservation area (Balai Taman Nasional Sebangau, 2015).

The indigenous Dayak continued to demand greater flexibility in utilizing the forest resources using claims of custom. However, hunting, fishing, and collecting forest products in areas within the restricted core and buffer zones were still restricted by the SNPA. Unfortunately, some indigenous leaders identified several sacred areas located within the zones. Further, wood is still needed by the locals to build houses and boats, which are essential for fishing activities. In general, the prohibition of human activities in conservation areas forced customary users to switch to alternative livelihood options. The SNPA encourages local people to practice farming/agro-livestock activities and fish culture. For example, loggers and sawmill workers have had to learn how to work as fishermen, NTFP collectors, or farmers. However, such abrupt cultural change cannot be easily adopted by everyone. Many local people, specifically the young, resisted adopting the new livelihood strategies, and opted instead to leave the village to work in distant regions, such as in oil palm plantations, to earn income, as they lacked the capital required to start farming.

\section{Livelihood hardships and limited alternative options}

The establishment of the SNP and the eventual closure of most of Sebangau forest from human intervention have forced local communities to drastically change their livelihood strategies. As previously mentioned, these communities have been encouraged to engage in farming as an alternative for their direct livelihood from forests. The migrants who used to work in logging operations have experienced hardship, particularly in the early period after logging closures.

[Nowadays], it is really difficult. Now, working for a day is only sufficient to afford food for the day. In the past, a day's work was more than enough for a week. The price of rice is very expensive now. We used to eat two plates full of rice, but now we could only afford to eat a quarter of a plate. It is a big difference. (An exlogger living in Baun Bango)

Nevertheless, the migrants, particularly those from Java, have gradually adjusted to new livelihood activities due to their historical farming culture. In contrast, the indigenous Dayak groups have found it more difficult, as their livelihoods were traditionally based on forest extraction 
activities. For instance, the cutting of trees, which is essential for building boats and houses, is now strictly prohibited. A Dayak leader in Kereng Bangkirai shared the following:

If local communities' activities in the forest are banned or prohibited, they cannot live anymore, or at least they will become impoverished. This is going to kill them slowly, because they are not used to living in the city, but they are used to living in the forest. Furthermore, we only support the changing status of the Sebangau forest to a conservation area or a national park if it benefits local communities. If it does not benefit them, then the local communities will become poor. If we become poor, we don't want this forest to be changed to a national park.

Our household survey was conducted in three research villages during the early stages of the establishment of the SNP. This survey identified the challenges faced by the local people as they were forced to shift to non-forest-based livelihood options. Results revealed that approximately $30 \%$ of the respondents (mostly Dayaks) lived in poverty. Their average income was well under the province's poverty line, which was defined at IDR 269,940/month in 2012 (BPS Kota Palangka Raya, 2012). We do not have quantitative figures of the poverty in the research areas prior the establishment of the SNP. This could serve as a caveat. Nonetheless, our survey could indicate the impacts of the park establishment on the people's livelihood. During the survey, our respondents also mentioned the economic hardships experienced by the people. Amidst the imposed restrictions to collect forest products for their subsistence needs, they experienced economic hardships. Many people do not have a proper house or basic home appliances. Furthermore, they lack adequate land to practice permanent farming. During the early conservation period, the local communities were further frustrated by the limited aid from the SNPA to identify livelihood alternatives as it had been more occupied with the tasks of conservation and protection of the forest resources. As one participant from the FGD in Baun Bango Village explained:

Ionce wanted to try to plant rubber, because people said that in 10 years it could be tapped. But in this village the soil is less fertile. It is clay. It was once suggested to add salt to increase fertility, but we couldn't afford to buy the required amount of salt. Not to mention that the use of salt is said to cause side effects. I was also advised to use fertilizer, but I could not afford the fertilizer. Finally, I tried to work at oil palm plantations in the surrounding villages.

It was only in recent times that the SNPA began to provide aid to the local people to identify and practice alternative livelihood strategies. The support included engaging local people in forest rehabilitation activities as paid workers and sporadically providing them with training, supplying them with tree seedlings and farming tools, and linking commodities produced by the locals to the markets. However, the SNPA stated that they were constrained by the limited budget. Indeed, the park authorities' main priority is the stabilization of the conservation area, i.e., preventing human disturbance, instead of economic empowerment of local communities. The support is provided mostly to "more cooperative" villages/individuals according to the SNPA's administrators. In effect, this meant that those communities that were opposed to the conservation policy and transformation of the park were largely ignored. A source from the SNPA suggested that this "reward and punishment approach" is essential to gaining local support for forest conservation as well as serving as a deterrent measure for the opposition. Hence, the Dayak communities are not given the same opportunity to navigate the adverse economic impacts of the park's establishment.

More importantly, the types of assistance were pre-determined by the authorities without prudent assessment and consultation with the local people. For instance, collecting gemor tree bark is only permitted when the communities do not cut the trees. However, a community leader reported that this was technically not possible. In many cases, the assistance did not meet the local needs. In fact, interviews and FGDs conducted in Kereng Bangkirai revealed that the local people demanded the use of the traditional zones for harvesting endemic tree species (e.g., jelutung and gemor) and fish culture to mitigate the restricted access to wild fishing. However, those demands have so far been ignored.

Meanwhile, the park manager stated that such activities are outside the park's tasks and 
responsibilities even though the current regulatory frameworks allow human activities within the utilization zone. The SNPA argued that the activity can instead be facilitated by the watershed rehabilitation bureau (BPDAS) and local forest services under the existing social forestry schemes. Requests to use the traditional zones for resin extraction are also granted, but to a limited extent only. The strict prohibition of timber cutting has made it more difficult, as logs are needed to haul solid resin. Overall, local communities remain constrained in utilizing the zones formally dedicated for them. As a result, their efforts to navigate the adverse economic impacts have increasingly become more challenging.

\section{Conclusions and policy recommendations}

Although the establishment of conservation areas is a central strategy to address deforestation, forest degradation, and climate change, too many conservation areas with strong ecological goals may overlook the socioeconomic and cultural requirements of the surrounding local communities (Infield et al., 2017; Abukari \& Mwalyosi, 2020). Our research in the SNP, located in Central Kalimantan, indicated that the establishment and management of the protected area failed to integrate the sociological and cultural dynamics of the local communities. Thus, in this study, we used an environmental justice lens to identify which types of claims of injustice were made by different stakeholders.

From a distributional perspective, we demonstrated that while all local people were adversely affected by the establishment of the SNP through the loss of their main livelihoods, the Dayak people sustained more negative impacts than migrant communities, as the former lacked land for farming and their customary practices were intertwined with the forests to which their access had been severely restricted. We showed that their ability to meet daily needs deteriorated, thereby making the local people more vulnerable to poverty.

From a procedural justice perspective, the SNP's establishment was directed by the central government without adequate consultation. Moreover, the conservation policy was imposed without prior consent from the local people. Meetings and public consultations were held only to meet the regulatory frameworks. Thus, such events only served as a symbolic gesture without substance. The voices of local people were often neglected, thus leading to the escalated tensions and conflicts with SNPA.

From a recognition perspective, the establishment and management of the SNP failed to consider the different customs and practices among different various ethnicities and cultures. The options made available for local livelihoods were limited and did not meet the specific needs and demands of certain ethnic groups, especially the Dayak people. Overall, the change of the Sebangau forest into a conservation area disrupted the locals' livelihood and led to pronounced adverse economic, social, and cultural impacts.

In light of the above, improving the social acceptability of the national park is essential not only for addressing the socioeconomic and cultural concerns of the locals, but also for achieving the SNP's ecological goal itself. The SNPA must also meaningfully engage the local communities in decisionmaking procedures because they are directly impacted by the establishment of the national park. In doing so, authorities must understand and adjust to the different sociocultural dynamics of the local people surrounding the park. Given that our research clearly elucidates disruptions in local livelihood, the SNPA must be able to identify and offer improved livelihoods alternatives that are socially and culturally acceptable.

One of the crucial issues we have identified is related to gazettement and zoning. Such a process must be carried out by involving local communities even before the gazettement begins. Furthermore, the involvement of local communities should not only be done symbolically; rather, it but entails providing them with a real understanding of the impacts that may be experienced as a result of the project. Furthermore, local communities should be involved in management so as to increase their sense of ownership. Reviews on the zonings are also essential to reflect the economic, social, and cultural needs of the local communities. The types and levels of human activities/interventions must be properly negotiated between the park authorities and the local communities. Specifically, alternative livelihood options, particularly for indigenous Dayak, should accommodate customary practices, such as fishing and collecting resin from jelutung and gemor. 
Local species should be allowed to be cultivated in areas dedicated to the local communities' livelihood activities. Moreover, local species could be considered within the 40,000 hectares of the national park in need of rehabilitation and reforestation (Balai Taman Nasional Sebangau, 2012), into which local species can be integrated. The SNPA may also consider providing continuous training to improve the local communities' skills and capacities while engaging in alternative forms of livelihood.

Recently, the SNPA promoted ecotourism as a new livelihood option, specifically in Kereng Bangkirai and Mekar Tani (Meilani et al., 2019). However, the promotion of ecotourism needs to be carefully considered together with the local people. To some extent, ecotourism has been regarded as a good solution to reconcile conservation and economic goals. However, Muller (2000) argues that ecotourism is neither good for solving conservation and environmental problems nor an economic bonanza. In the ideal scenario, a clear picture of the opportunities and costs should be well communicated to the local people to determine whether they are suitable and acceptable in relation to local sociocultural elements.

Author Contributions: AM was the main research supervisor together with MM; WA and LRWF conceived and designed the research; MM conducted fieldwork and analyzed the data; FDS contributed to data analysis; and $\mathrm{MM}$ and $\mathrm{AM}$ contributed to data analysis and wrote the paper.

Conflicts of Interest: The authors declare no conflict of interest.

Acknowledgments: The authors would like to thank the Rekognisi Tugas Akhir (RTA) 2021 of Universitas Gadjah Mada (Grant No. 3143/UN1.P.III/DIT-LIT/PT/2021) for supporting this research. The authors are also grateful to the government officials of the Ministry of Environment and Forestry; the SNP Authority; the residents of Mekar Tani, Baun Bango, and Kereng Bangkirai; the Provincial Government of Central Kalimantan; WWF-Indonesia; ecotourism experts and practitioners; and all the involved colleagues who supported the fieldwork.

\section{References}

Abukari, H. \& Mwalyosi, R. B. (2020). Local Communities' Perceptions about the Impact of Protected Areas on Livelihoods and Community Development. Global Ecology and Conservation, 22, E00909. https://doi.org/10.1016/j.gecco.2020.e00909

Agrawal, A. \& Redford, K. (2009). Conservation and Displacement: An Overview. Conservation and Society, 7(1), 1-10. http://dx.doi.org/10.4103/0972-4923.54790

Baker, J., Milner-Gulland, L.-W., \& N. (2011). Park Gazettement and Integrated Conservation and Development as Factors in Community Conflict at Bwindi Impenetrable Forest, Uganda. Conservation Biology, 26(1), 160-170. https://doi.org/10.1111/j.1523-1739.2011.01777.x

Badan Pusat Statistik Kota Palangka Raya. (2012). Kota Palangka Raya Dalam Angka Tahun 2012. Badan Pusat Statistik Kota Palangka Raya.

Balai Taman Nasional Sebangau (2007a). Rencana Kerja Lima Tahun Periode 2007-2011. Departemen Kehutanan, Dirjen Perlindungan Hutan dan Konservasi Alam, Balai Taman Nasional Sebangau.

Balai Taman Nasional Sebangau (2007c). Rencana Pengelolaan Taman Nasional Sebangau Periode 2007-2026. Direktorat Jenderal Perlindungan Hutan dan Konservasi Alam.

Balai Taman Nasional Sebangau (2007d). Rencana Pengembangan Ekonomi Masyarakat Di Dalam dan Di Sekitar Kawasan Konservasi di Wilayah Balai Taman Nasional Sebangau Tahun 20072009. Balai Taman Nasional Sebangau.

Balai Taman Nasional Sebangau (2010a). Rencana Pengembangan Wisata Alam Taman Nasional Sebangau. Balai Taman Nasional Sebangau.

Balai Taman Nasional Sebangau (2012). Laporan Tahunan Balai Taman Nasional Sebangau Tahun 2011. Balai Taman Nasional Sebangau.

Balai Taman Nasional Sebangau (2015). Zonasi Taman Nasional Sebangau. Balai Taman Nasional Sebangau.

Balmford, A. \& Whitten, T. (2003). Who Should Pay for Tropical Conservation, and How Could the Costs Be Met? Oryx, 37(2), 238-250. https://doi.org/10.1017/\$0030605303000413 
Bong, I.W., Felfer, M.E. Maryudi, A. (2016). How Are Local People Driving and Affected by Forest Cover Change? Opportunities for Local Participation in REDD+ Measurement, Reporting and Verification. Plos One 11, 1-17. https://doi.org/10.1371/journal.pone.0145330

Bennett, N. J. \& Dearden, P. (2014). Why Local People Do Not Support Conservation: Community Perceptions of Marine Protected Area Livelihood Impacts, Governance and Management in Thailand. Marine Policy, 44, 107-116. https://doi.org/10.1016/j.marpol.2013.08.017

Bertzky, B., Corrigan, C., Kemsey, J., Kenney, S., Ravilious, C., Besançon, C., \& Burgess, N. (2012). Protected Planet Report 2012: Tracking Progress Towards Global Targets for Protected Areas. Gland, Switzerland: IUCN and UNEP-WCMC, Cambridge, UK.

Boillat, S., Gerber, J.-D., Oberlack, C., Zaehringer, J. G., Ifejika Speranza, C. I., \& Rist, S. (2018). Distant Interactions, Power, and Environmental Justice in Protected Area Governance: A Telecoupling Perspective. Sustainability, 10(11), 3954. https://doi.org/10.3390/su10113954

Dahlberg, A., Rohde, R., \& Sandell, K. (2010). National Parks and Environmental Justice Comparing Access Rights and Ideological Legacies in Three Countries. Conservation and Society, 8(3), 209224. https://doi.org/10.4103/0972-4923.73810

Elmhirst, R. (2011). Migrant Pathways to Resource Access in Lampung's Political Forest: Gender, Citizenship and Creative Conjugality. Geoforum, 42(2), 173-183. https://doi.org/10.1016/j.geoforum.2010.12.004

Fatem, S. M., Awang, S. A., Pudyatmoko, S., Sahide, M. A. K., Pratama, A. A., \& Maryudi, A. (2018). Camouflaging Economic Development Agendas with Forest Conservation Narratives: A Strategy of Lower Governments for Gaining Authority in the re-Centralising Indonesia. Land Use Policy, 78, 699-710. https://doi.org/10.1016/j.landusepol.2018.07.018

Gustavsson, M., Lindström, L., Jiddawi, N. S., \& de la Torre-Castro, M. (2014). Procedural and Distributive Justice in a Community-Based Managed Marine Protected Area in Zanzibar, Tanzania. Marine Policy, 46, 91-100. https://doi.org/10.1016/j.marpol.2014.01.005

Hannah, L. (2008). Protected areas and climate change. Annals of the New York Academy of Sciences, 1134(1), 201-212. http://dx.doi.org/10.1196/annals.1439.009

Hart, C. R. (2014). The Role of Environmental Justice in Biodiversity Conservation: Investigating Experiences of Communities near Kruger National. Park, South Africa. Dalhousie Journal of Interdisciplinary Management, 10(1), 1-16. https://doi.org/10.101610.5931/djim.v10i1.3359

Hulme, D. \& Murphree, M. (1999). Communities, Wildlife and the 'New Conservation' in Africa. Journal of International Development, 11(2), 277-285. https://doi.org/10.1002/(SICI)10991328(199903/04)11:2\%3C277::AID-JID582\%3E3.0.CO;2-T

Infield, M. (2001). Cultural Values: A Forgotten Strategy for Building Community Support for Protected Areas in Africa. Conservation Biology, 15(3), 800-802. http://dx.doi.org/10.1046/j.1523-1739.2001.015003800.x

Infield, M., Entwistle, A., Anthem, H., Mugisha, A., \& Phillips, K. (2017). Reflection on Cultural Values Approaches to Conservation: Lesson from 20 Years of Implementation. Oryx, 52(2), 1-11. https://doi.org/10.1017/s0030605317000928

Laraswati, D., Rahayu, S., Pratama, A.A.; Soraya, E., Sahide, M.A.K.; Maryudi, A. (2020). Problemmethod fit in forest policy analysis: Empirical pre-orientation for selecting tested or innovative social-qualitative methods. MethodsX, 7: 100794. https://doi.org/10.1016/j.mex.2020.100794

Martin, A., McGuire, S., \& Sullivan, S. (2013). Global Environmental Justice and Biodiversity Conservation. The Geographical Journal, 179(2), 122-131. https://doi.org/10.1111/geoj.12018

Martin, A., Coolsaet, B., Corbera, E., Dawson, N. M., Fraser, J. A., Lehmann, I., \& Rodriguez, I. (2016). Justice and Conservation: The Need to Incorporate Recognition. Biological Conservation, 197, 254-261. https://doi.org/10.1016/j.biocon.2016.03.021

Maryudi, A., Acheampong, E., Rutt, R.L.; Myers, R., McDermott, C.L. (2020). "A Level Playing Field"? What an Environmental Justice Lens Can Tell us about Who Gets Leveled in the Forest Law Enforcement, Governance and Trade Action Plan. Society \& Natural Resources, 33(7), 859-875. https://doi.org/10.1080/08941920.2020.1725201

Maryudi, A., Myers, R. (2018). Renting legality: How FLEGT is reinforcing power relations in Indonesian furniture production networks. Geoforum, 97: 46-53. https://doi.org/10.1016/j.geoforum.2018.10.008 
Meilani, M.M., Andayani, W., Faida, L.R.W., Maryudi, A. (2019). Ecotourism in Sebangau National Park: an avenue to enhance local community livelihoods while protecting the ecosystem. IOP Conference Series: Earth and Environmental Science 399(1), 012112. https://iopscience.iop.org/article/10.1088/1755-1315/399/1/012112

Müller, F. G. (2000). Ecotourism: an economic concept for ecological sustainable tourism. International Journal of Environmental Studies, 57(3), 241-251. https://doi.org/10.1080/00207230008711271

Myers, R., \& Muhajir, M. (2015). Searching for justice: rights vs 'benefits' in Bukit Baka Bukit Raya national park, Indonesia. Conservation and Society, 13(4), 370-381. https://doi.org/10.4103/0972-4923.179886

Nurrochmat, D. R., Nugroho, I. A., Hardjanto, Purwadianto, A., Maryudi, A., Erbaugh, J. T. (2017). Shifting Contestation into Cooperation: Strategy to Incorporate Different Interest of Actors in Medicinal Plants in Meru Betiri National Park, Indonesia. Forest Policy and Economics, 83, 162 168. https://doi.org/10.1016/j.forpol.2017.08.005

O'Riordan, T. \& Stoll-Kleeman, S. (2002). Biodiversity, Sustainability and Hunam Communities: Protecting beyond the Protected. Cambridge University Press.

Persoon, G. A. (2004). Stakeholders, Right-Holders, and Care-Takers, Present and Future Actions in the Sebangau Area (Central Kalimantan): A Report for the Sebangau Orang Utan Conservation Project (Based on The 8-20 March 2004 Mission). Retrieved from Palangkaraya/Leiden.

Persoon, G. A. \& Aliayub, A. (2002). A Socio-Economic Profile of the Sebangau Watershed Area, Central Kalimantan. Retrieved from Palangkaraya.

Rahayu, S., Laraswati, D., Pratama, A.A., Permadi, D.B. Sahide, M.A.K., Maryudi, A. (2019). Research trend: Hidden diamonds-The values and risks of online repository documents for forest policy and governance analysis. Forest Policy and Economics, 100, 254-257. https://doi.org/10.1016/j.forpol.2019.01.009

Rahman, H. M. T., Hickey, G. M., \& Sarker, S. K. (2012). A Framework for Evaluating Collective Action and Informal Institutional Dynamics under a Resource Management Policy of Decentralization. Ecological Economics, 83, 32-41. https://doi.org/10.1016/j.ecolecon.2012.08.018

Samsu, Komarudin, H., McGrath, S., Ngau, Y., \& Suramenggala, I. (2004). Small Scale 100 Ha Logging Concessions' Contribution to Regional Finance: Case Study in Bulungan District. CIFOR.

Schlosberg, D. (2013). Theorising Environmental Justice: The Expanding Sphere of a Discourse. Environmental Politics, 22(1), 37-55. https://doi.org/10.1080/09644016.2013.755387

Schreckenberg, K., Franks, P., Martin, A., \& Lang, B. (2016). Unpacking equity for protected area conservation. Parks, 22(2), 11-26. https://doi.org/10.2305/IUCN.CH.2016.PARKS-22-2KS.en

Schroeder, R., Martin, K., Wilson, B. \& Sen, D. (2008). Third World Environmental Justice. Society \& Natural Resources, 21(7), 547-555. https://doi.org/10.1080/08941920802100721

Setiawan, E. N., Maryudi, A., Purwanto, R. H., \& Lele, G. (2016). Opposing Interests in the Legalization of Non-Procedural Forest conversion to Oil Palm in Central Kalimantan, Indonesia. Land Use Policy, 58, 472-481. https://doi.org/10.1016/j.landusepol.2016.08.003

Shoyama, K., Managi, S., Yamagata, Y. (2013). Public preferences for biodiversity conservation and climate-change mitigation: A choice experiment using ecosystem services indicators. Land Use Policy, 34, 282-293. https://doi.org/10.1016/j.landusepol.2013.04.003

Sikor, T., (2013). The Justices and Injustices of Ecosystems Services: Routledge.

Soehartono, T. \& Mardiastuti, A. (2013). The Voice of National Parks in Kalimantan, Indonesia: Searching the Truth of Thirty Year National Park Development. Nata Samastha Foundation.

Tauli Corpuz, V. (2016). Report of the Special Rapporteur of the Human Rights Council on the Rights of Indigenous Peoples. Retrieved from

http://unsr.vtaulicorpuz.org/site/index.php/en/documents/annual-reports/149-reportga2016.

UNEP (2020). Protected Planet Report. WCMC, IUCN and NGS. UNEP-WCMC, IUCN and NGS: Cambridge, UK; Gland, Switzerland; and Washington, D.C., USA. Retrieved from https://livereport.protectedplanet.net/chapter-22020-Chapter2

Walker, G. (2012). Environmental Justice: Concepts, Evidence and Politics. Routledge. 